Max-Planck-Institut für demografische Forschung

Max Planck Institute for Demographic Research

Doberaner Strasse 114 - D-18057 Rostock · GERMANY

Tel +49 (0) 3812081 - 0; Fax +49 (0) 3812081 - 202;

http://www.demogr.mpg.de

MPIDR WORKING PAPER WP 2002-027

JUNE 2002

\title{
The Differential Influence of Women's Residential District on the Risk \\ of Entering First Marriage and \\ Motherhood in Western Germany
}

Karsten Hank (hank@demogr.mpg.de)

This working paper has been approved for release by: Hans-Peter Kohler (kohler@demogr.mpg.de) Head of the Research Group on Social Dynamics and Fertility.

(C) Copyright is held by the authors.

Working papers of the Max Planck Institute for Demographic Research receive only limited review. Views or opinions expressed in working papers are attributable to the authors and do not necessarily reflect those of the Institute. 


\title{
The Differential Influence of Women's Residential District on the Risk of Entering First Marriage and Motherhood in Western Germany
}

\author{
Karsten Hank ${ }^{\star}$
}

\begin{abstract}
This paper investigates the role of women's residential district in the process of family formation in western Germany during the 1980s and 1990s. Our analysis of the transition to first marriage and motherhood is based on the German Socio-Economic Panel (GSOEP), which we merge with a rich set of district-level data. The estimated multilevel discrete-time logit models suggest that (1) basically all regional heterogeneity in women's entry into parenthood is due to differences in the respondents' marital status, while there is (2) a constant and significant regional variation in women's first marriage probabilities, which cannot be explained by population composition or structural contextual effects. Thus, regional influences on fertility behavior do not have an autonomous quality, but are merely mediated through a latent contextual effect on women's risk of entering first marriage, which we attribute to regional socio-cultural milieus.
\end{abstract}

Keywords: family formation; multilevel analysis; Germany

* Author's correspondence address: Max Planck Institute for Demographic Research, Doberaner Str. 114, 18057 Rostock, Germany. Telephone: +49-381-2081-163. Fax: +49-3812081-463.Email: hank@demogr.mpg.de.

I am greatly indebted to Johannes Huinink and Hans-Peter Kohler for many helpful comments and suggestions. Kind support of the GSOEP-Team during a research visit at the DIW Berlin is gratefully acknowledged.

The views expressed in this paper are the author's views and do not necessarily reflect those of the Max Planck Institute for Demographic Research. 


\section{Introduction}

In recent years, contextual effects on family-related events have gained considerable attention in the demographic literature (e.g., Billy and Moore 1992; South 2001; South and Crowder 2000; Teachman and Crowder 2002). However, with the exception of a few fertility studies in Scandinavian countries (Hoem 2000; Kravdal 1996; Kravdal 2002), there has so far barely been any such research for the European setting. This paper contributes to filling in the gap, focussing on the process of family formation in western Germany.

Although social scientists' attention in post-unification Germany has been attracted primarily by the rapid fertility decline in eastern Germany and by the question of whether fertility levels in East and West will converge over time, two studies were conducted lately, which began to investigate whether regional differentials in reproductive behavior within both parts of the country persist, once individual characteristics are controlled for in the analysis. While Kopp (2000) uses data on seven selected Kreise (i.e. districts) from a regionalized survey, Hank (2002a) links individual-level data from the German Socio-Economic Panel with information on western German Raumordnungsregionen, i.e. 75 spatial units defined for the analysis of regional disparities and developments. These studies suggest that much of the variation in childbearing patterns between German regions (see Hank [2001] for details) is due to differences in the respective population composition, particularly regarding age, education, and marital status. An analysis of the geographic context of male nuptiality, though, finds support for the hypothesis that in western Germany increasing economic independence of women at the regional level results in slower transition rates to 
marriage. It furthermore indicates that men's propensity to marry might be influenced by the regional socio-cultural milieu they live in (cf. Hank 2002b).

Continuing this research, the present paper employs multilevel discrete-time logit models to estimate - for the first time - contextual influences on western German women's probabilities to enter first marriage and motherhood during the 1980s and 1990s. Given the close relationship between the two events (e.g., Billari and Kohler 2002; Konietzka and Kreyenfeld 2002), such a joint consideration within a single analytical framework is highly desirable. We use the German Socio-Economic Panel (GSOEP) as an individual-level data source. The social context is operationalized at the level of 328 Kreise, which represent the smallest regional units for which data are available.

\section{Individual and contextual determinants of family formation}

To avoid committing what Hauser (1974) calls the 'contextual fallacy', researchers carefully need to consider what might be important 'controls' for the individual's background, and through which processes aggregate-level effects operate on individual behavior. Jencks and Mayer (1990: 113), for example, distinguish among epidemic (or contagion) models, collective socialization (or social control) models, and institutional models of contextual effects. Hank (2002a) argues that regional opportunity structures as well as local patterns of social interaction and culture may translate into parameters that directly affect individual decision-making.

In the following, a set of hypotheses is proposed that briefly describes our key assumptions about the relationship between regional social contexts and women's 
family formation decisions. The choice of relevant regional variables is partly determined by the availability of data for a subsequent empirical analysis. Since the individual-level control variables have been shown in prior studies to influence fertility and marital behavior, they will not be discussed in greater detail.

\section{Individual characteristics}

An individual's age clearly is the most important biosocial determinant of her position in the life-course. A non-monotonic effect is assumed, i.e. women's propensity to enter marriage and motherhood should first increase with age, but decrease at later stages of her life course.

The influence of an individual's human capital characteristics on the process of family formation has been analyzed extensively not only within the framework of the 'new home economics' (e.g., Becker 1993: Chapter 5), but also from the perspective of sociologists (e.g., Blossfeld and Huinink 1991) and demographers (e.g., Rindfuss et al. 1996). Due to higher investments in human capital, more highly educated women (i) gain economic independence and face higher opportunity costs of childrearing than their less educated counterparts, but at the same time (ii) they are more attractive partners on the marriage market and have a greater economic potential to support a family. Thus the direction of the level-of-education-effect on the individual's propensity to form a family cannot be predicted unambiguously. In any case, a woman's risk of entering marriage and/or parenthood should be lowest, as long as she is enrolled in education. 
Finally, having a child (being married, respectively) as well as having a foreign background $^{1}$ is supposed to increase a woman's probability to enter marriage (motherhood, respectively).

\section{Regional characteristics}

One of the main determinants of the living conditions in an individual's environment are local opportunity structures. These should be reflected in part by the degree of urbanization. Since urban areas generally offer more alternatives to traditional family formation and provide a less appropriate environment for rearing children than rural areas, it is assumed that women exhibit a decreasing propensity to marry and have a child, if the population density of their residential district increases (e.g., Huinink and Wagner 1989; Lichter et al. 1991).

A shortage in the number of desirable partners on the marriage market, e.g. due to an imbalanced sex ratio, often leads to relatively high proportions unmarried or to a delay of marriage. Hence, it is generally predicted that women encountering numerous men in the local marriage market will have high marriage rates (e.g., South and Lloyd 1992a; 1992b).

Access to children's day care plays a crucial role for the compatibility of childrearing and female employment and therefore becomes a central element of a region's opportunity structure. Since the availability of adequate child care reduces the opportunity costs of childrearing for women who want to participate in the labor force, a

\footnotetext{
${ }^{1}$ In western Germany, so called 'guest workers' - mainly from southern Europe and Turkey and their descendants account for the largest share of the foreign population. These citizens are likely to have more traditional values than their native German counterparts.
} 
woman should be more likely to have children if the public provision of day care increases (e.g., Kravdal 1996; see also the discussion in Hank and Kreyenfeld 2002).

The availability of jobs in the tertiary sector is frequently considered to favor women's career prospects (e.g., Blossfeld 1987), which should increase women's economic independence and the opportunity costs of motherhood. Thus it is assumed that a woman's probability of getting married and having a child decreases, if the share of jobs in the service sector increases.

The direction of an effect of the regional unemployment rate on fertility is difficult to predict (see Kravdal [2002: Section 3] for a discussion). Since the labor supply of women partly depends on the demand for labor, a woman's probability to have a child is supposed to move in step with the unemployment rate, because (at least in the short run) this would reduce the opportunity costs of cutting down or giving up market work for starting a family. On the other hand, the local labor market situation is an indicator of a community's socio-economic status and the economic situation in general. Thus women are expected to be more likely to have a child if unemployment decreases, since children might be considered as being more affordable, if economic prospects are evaluated positively (e.g., Hoem 2000: Section 5).

The regional unemployment rate may also have an ambiguous influence on women's entry into marriage. If the labor market situation is perceived as difficult, women could seek economic security in a marriage, where they pool their income with the partner's earnings. However, high unemployment also reduces the number of economically attractive partners on the marriage market, which might result in delayed marriage (e.g., Lichter et al. 1991). 
The total effect of the aggregate female labor force participation on family formation is unclear, too (cf. Brewster and Rindfuss [2000] for a recent review). Female employment rates clearly mark the degree to which women are expected and able to constitute economic independence from a husband's support. Since the motivation to work in the market (and delay or even forgo traditional family formation) is supposed to be positively affected by the role model of other women, a woman's propensity for having a child and contracting a marriage should decrease with an increasing female labor force participation rate. However, a high labor force participation of women could also induce favorable changes in the interplay between the family and labor market institutions, which might eventually account for the needs of working mothers. Thus a woman's probability to have a child may even increase with a growing participation of women in the labor market.

Finally, actors are likely to be influenced by behavioral expectations and actual behavior they witness in their social environment. South and Crowder (2000: 1069), for example, point out that socially dislocated areas might "lack successful marital role models that signal the benefits of marriage and provide the normative expectations to marry." Moreover, there is accumulating evidence suggesting the existence of age- and sequencing-norms related to a variety of family transitions (e.g., Blossfeld and Huinink 1991; Settersten and Hägestad 1996). Since 'conservative' cultural forces are assumed to have a stronger effect in homogeneous social contexts, a woman's propensity to form a family is supposed to be higher in areas characterized by high marriage rates (birth rates, respectively) and a single predominant ideational orientation, which may be expressed by denominational affiliation or by support for a political party (e.g., Lesthaeghe and Surkyn 1988). 


\section{Data and methods}

\subsection{Data, variables, and description of the samples}

The individual-level data used in this paper were made available by the German SocioEconomic Panel Study (GSOEP) at the German Institute for Economic Research (DIW Berlin) (see SOEP Group [2001] for a description of the data set). This longitudinal micro-database provides socio-economic information on currently more than 7,000 households (including an oversample of foreign-headed households) and 14,000 individuals in eastern and western Germany. The survey was started in the western states of Germany and is conducted annually since 1984. The full marital history and birth biography of all women who participate in the survey is provided with the data. Only the transition to the first marriage and to the first child will be considered here.

The GSOEP can be linked to Kreise, i.e. district-level data. The population size of Kreise ranges from roughly 50,000 to around 700,000, averaging at about 200,000 (cities of one million or more inhabitants excluded). Among the 328 western German Kreise (including West-Berlin), it is possible to distinguish between urban kreisfreie Städte and rural Landkreise. The latter cover on average about 30 municipalities, while the former usually consist of a single urban municipality only.

The observation period covers the years 1984 to 1999 . Unfortunately, information on the regional variables of interest is mostly available for two points in time only. The 'DJI Regionaldatenbank' provides regional indicators at the Kreis level for the second half of the 1980s (see http://www.dji.de for further information), while regional information for the mid-1990s is drawn from the 'Statistik regional' database 
(Statistische Ämter des Bundes und der Länder 1999). The observation period is therefore divided into two halves, from 1984 to 1991, and from 1992 to 1999 , respectively. Time-varying contextual variables are assumed to be time-constant within each of the two periods, and are allowed to vary only between the two periods defined above.

Table 1 provides an overview of the individual-level and contextual variables that will be used in the empirical analysis.

[Table 1 about here]

Only respondents from the two original GSOEP subsamples are included in the analysis, i.e. western Germans and foreigners from Greece, Italy, Spain, Turkey, and former Yugoslavia, who already lived in Germany in 1984. Individuals who move during the study period from one Kreis to another are followed to their new place of residence. The sample for the analysis of first marriages is restricted to 2,266 nevermarried women, who are observed from age 20 onwards, unless this age was reached before the first year of observation. The upper age limit is 35 years. Since each individual is allowed to contribute multiple observations, this leads to 10,077 individual records, nested within 288 Kreise (out of 328 Kreise in the population). The number of observed first marriages in the period 1984 to 1999 is 746 . The sample for the analysis of first births consists of 2,892 women aged 20 to 35 who live in 300 Kreise. This results in 13,537 individual records and 1,025 events. See Table 2 for further descriptive sample statistics.

[Table 2 about here] 


\section{$\underline{3.2 \text { Methods }}$}

This study uses discrete-time multilevel models to estimate a woman's risk of entering first marriage (motherhood, respectively) within a one-year interval in the observation period (see Barber et al. [2000] for a thorough methodological discussion). A common choice to specify how the discrete-time hazard rate is determined, is the logistic regression function. The logit model provides a good approximation to the continuous time proportional hazards model, if the conditional probabilities that an event occurs at time $t$, given that it has not already occurred, are sufficiently small (Yamaguchi 1991).

The discrete-time logit model estimates the effect of a number of covariates on the $\log$ of the odds of an event. However, if individuals are clustered within the same context, the standard assumption of independent disturbances is violated. This may result in inefficient estimates of the macro-level parameters and downwardly biased estimates of their standard errors. Hierarchical generalized linear models - as an extension of random coefficient models - can be used to overcome these problems. They allow the application of multilevel logistic regression models for the analysis of discrete dependent variables (see Guo and Zhao [2000] for an overview). In these models, coefficients may be fixed or random, where the choice between the two alternatives can be made separately for each coefficient in the equation. In the analysis performed here, all regression coefficients other than the intercept are constrained to be fixed across the regional units, i.e. we assume that the effect of the explanatory variables does not differ between contexts ('random intercept model'; see Snijders and Bosker [1999: Chapter 4]).

In the present case, the log odds that a woman experiences the event under consideration (i.e. first marriage or first birth) within the one-year interval $t$ is 


$$
\log \left[p_{i j t} /\left(1-p_{i j t}\right)\right]=b_{0}+b_{1} x_{i j}+b_{2} z_{i j t}+b_{3} v_{j}+b_{4} w_{j t}+u_{0 j}
$$

where $p_{i j t}$ is the probability of individual $i$ in region $j$ to marry (give birth, respectively) in year $t, x_{i j}$ and $v_{j}$ are vectors of individual- and macro-level time-constant explanatory variables, and $z_{i j t}$ and $w_{j t}$ are vectors of time-varying explanatory variables at time $t$. The random intercept's fixed component $b_{0}$ - which is constrained to be equal across all years - and the slopes $b_{1}$ to $b_{4}$ are the parameters of the equation. The macro-level error term $u_{0 j}$ is the regional-level random coefficient, where the same $u_{0 j}$ applies to all observations in a particular region. It indicates that the intercept may vary over contexts, i.e. $u_{0 j}$ measures the deviation of each context from $b_{0}$ ('between-context variance'). This captures otherwise unobserved regional effects and accounts for the correlation between individuals nested within the same context. The macro-level disturbances $u_{0 j}$ are assumed to be normally distributed, with the expected value 0 and the variance $\sigma_{u}^{2}$. If the variance of $u_{0 j}$ turns out to be statistically significant from zero, context effects are present. Since the entry into first marriage or motherhood is a non-repeatable event, no individual-level unobserved heterogeneity factor can be identified.

Discrete-time logit models use multiple observations for each individual in the sample, i.e. each time unit during which an individual is observed contributes a separate and independent observation to the input data. For each of these observations, the dependent variable is coded 1 if the event occurs, 0 otherwise.

\section{Regression results}

The results of the multivariate analysis are presented separately for first marriages and first births. Since our main interest is on contextual effects, the findings for the 
individual-level coefficients are only briefly reported. The final models are build-up in several steps, starting from an 'empty model' with just the intercept and the regional random effect (Model 1). The individual-level control variables are introduced in Models 2 to 4, and the district-level contextual variables are eventually added in Models 5 to 7 . The regression results for the analysis of women's entry into first marriage are displayed in Table 3, while the results for women's entry into motherhood are shown in Table 4. The analysis is performed using the software package $a M L$ (see Lillard and Panis [2000]).

\section{Entry into first marriage}

The coefficients of the individual-level control variables come out as expected. In addition to a non-monotonic age effect (Model 2), educational enrollment strongly reduces the propensity to enter first marriage (Model 3). Terminating education without degree is also found to reduce a woman's marriage risk, but the respective coefficient becomes statistically significant only after it is controlled for the presence of a child (Model 4). This indicates that the lower marriage propensity of women without degree is underestimated, if one does not account for their higher risk of unmarried childbearing, which subsequently leads to a higher probability to marry among mothers with no degree. Inclusion of the 'child' dummy substantially improves the overall model fit and has the anticipated strong and positive impact on the dependent variable. Finally, being a foreigner increases a woman's probability to contract a marriage (Model 4), although the coefficient is significant at the 10 per cent level only.

With regard to contextual influences, there is no statistically significant effect of any of the district-level variables introduced in Models 5 and 6. The coefficient of our 
ideational homogeneity index in Model 7 turns out to be weakly significant, however, with an unexpected negative sign. This points to the presence of unobserved confounding socio-cultural factors, which are captured by the regional random effect $\left(\sigma_{u}\right)$. The initial value of $\sigma_{u}$ is not reduced by any of the individual-level or contextual variables and remains highly significant throughout all models, which indicates that the intercept, i.e. the 'baseline log-odds' of entering first marriage, varies across Kreise.

Similar results are obtained, when men's entry into marriage is considered, yet Hank (2002b) additionally finds a negative effect of high female labor force participation on male transition rates to marriage.

[Table 3 about here]

\section{Entry into motherhood}

The direction of the effects of the individual-level control variables on the probability to enter motherhood is generally the same as in the 'nuptiality analysis' and thus consistent with our theoretical expectations. The risk of married western German women to experience a first birth is found to be many times higher than for their unmarried counterparts (Model 4). Including a woman's marital status in the analysis not only results in a substantial improvement of the model's fit, but also leads to a clear reduction in the initial size of the other individual-level coefficients. This extraordinarily strong impact is consistent with other research indicating a clear tendency towards 'child oriented' marriages in western Germany (e.g., Konietzka and Kreyenfeld 2002).

Turning to the contextual variables, we find a highly significant regional random effect on women's risk of entering motherhood in the 'empty' Model 1. As can be seen 
from Models 2 and 3, the contextual effect remains after age and education are controlled for. However, once the marital status is entered into the regression, $\sigma_{u}$ virtually disappears (Model 4). Adding the 'rural-urban' variables nevertheless leads to a weakly significant improvement of the fit in Model 5. The coefficient of the dummy variable indicating residence in a rural Kreis is statistically significant, and the direction of the effect is consistent with our hypothesis that women in less urbanized areas have a higher propensity of having a child. However, this effect becomes weaker and insignificant in Models 6 and 7, where additional regional variables are included in the analysis. None of these has an own measurable impact on a woman's first birth risk, though.

These findings are in line with results reported in Hank (2002a), where larger Raumordnungsregionen were used as regional context. This suggests that basically all regional heterogeneity in women's transition to parenthood should be due to differences in marital behavior, independent of the spatial definition of the context. If Model 7, for example, is run without controlling for the marital status (not shown here), we find significant coefficients for the 'rural' dummy (positive) and the female labor force participation rate (negative); the size of $\sigma_{u}$ then remains in the same order of magnitude as in models without any direct regional-level indicators.

[Table 4 about here]

\section{Discussion}

There are two main results of the multivariate analysis. First, we do not find evidence for a persistent autonomous influence of characteristics of the residential district on a 
woman's first birth risk. Consistent with a recent study that operationalizes the social context at a higher level of spatial aggregation (Hank 2002a), basically all regional heterogeneity in women's transition to parenthood appears to be due to differences in the respondents' marital status. Secondly, the multilevel discrete-time logit models for women's entry into first marriage show a constant and significant variation of the regression intercept across Kreise, which cannot be explained by population composition or structural contextual effects (see also Hank 2002b).

Regional differences in union formation, for which our measure of the crude marriage rate is apparently unable to account, are likely to be embedded in broader and probably longstanding socio-cultural contexts. An examination of the age at marriage and control of marital fertility in a variety of geographical settings indicates that at least in pre-transitional societies "the social context in which late marriage is the norm is one in which women have more autonomy and are freer to adopt control over their childbearing." (Coale 1992: 340) Although the historical structural circumstances that originally fostered later marriage in some areas (e.g. specific inheritance rules) may have changed, local subcultures that evolved in the demographic domain often turn out to be extremely stable across time (e.g., Lesthaeghe and Neels 2001; Reher 1998: 212ff.). The persistence of spatial differentials in family formation patterns should depend increasingly on variations in the spread of broader value orientations (e.g., Lesthaeghe and Moors 2000) and "internalized norms about age-appropriate behavior, age-graded events and transitions, and age-sequential rules [...] as societal regulation became more lenient." (Heckhausen 1999: 35; italics not in the original)

In the western German society, it is commonly expected that women complete education before marriage (e.g., Blossfeld and Huinink 1991), and marry before 
entering parenthood (e.g., Billari and Kohler 2002). ${ }^{2}$ Although longer enrollment in education leads to a general postponement of family formation, controlling for women's education in our analysis cannot explain regional variations in their probability of entering first marriage and motherhood. Neither are differentials in women's experience of premarital childbearing able to account for the observed district-level differences in marriage risks. Women's marital behavior, on the other hand, absorbs virtually all regional heterogeneity in their propensity to have a first child during the observation period. This, and the absence of structural contextual effects, suggests the existence of regional socio-cultural milieus, which might differ with regard to the commonness of premarital cohabitation or regarding collective expectations concerning the timing of marriage, for example. Hank (2002b) argues that variations in the degree of secularization may be considered as an underlying cause of regional heterogeneity in the propensity to contract a marriage. Eventually, this results in corresponding differentials in the birth of first and possibly subsequent children. Thus, regional influences on fertility behavior do not have an autonomous quality, but are merely mediated through a direct contextual effect on women's risk of entering first marriage.

Despite the insignificance of the regional child care and labor market indicators, one should not conclude that regional opportunity structures do generally not matter for an individual's family formation behavior. However, for the contemporary western German setting - and in spite of specific structural profiles of high- and low-fertility areas (see Hank 2001) - the overall degree of socio-economic development in all

\footnotetext{
${ }^{2}$ The situation in eastern Germany is entirely different. In 1989, every third child was born outof-wedlock, and ten years later the share of non-marital births even increased to 50 per cent (Konietzka and Kreyenfeld 2002).
} 
districts is apparently too high (and the variations therein too low) as to induce sizeable differentials in the costs and benefits of children for their parents.

Unfortunately, our analysis could reveal only indirect evidence concerning the nature of the relationship between regional social contexts and family formation behavior in western Germany. We are not able to distinguish, for example, between local customs (that women will marry at a certain age) and local norms (that women should marry at a certain age) (see Marini [1984] for a critical discussion). However, the identification of behaviorally relevant characteristics of regional socio-cultural milieus requires richer data than those that are usually available from social science surveys. Researchers should therefore make an effort to collect more qualitative data - possibly through ethnographic observation - that allow comparative studies of behavioral expectations, value orientations, etc., in a variety of spatial and social units. 


\section{References}

Barber, J.S., S.A. Murphy, W.G. Axinn, and J. Marples. 2000. "Discrete-time multilevel hazard analysis.” Pp.201-235 in Sociological Methodology, vol. 30, edited by M.E. Sobel and M.P. Becker. Washington: Blackwell Publishers.

Becker, G.S. 1993. A Treatise on the Family (Enlarged Edition). Cambridge: Harvard University Press.

Billari, F.C. and H.-P. Kohler. 2002. "The impact of union formation dynamics on first births in West Germany and Italy: Are there signs of convergence?" Forthcoming in Comparative Research on Fertility and the Family in Contemporary Europe: Findings and Lessons (Vol.2), edited by E. Klijzing and M. Corijn. New York and Geneva: United Nations.

Billy, J.O. and D.E. Moore. 1992. “A multilevel analysis of marital and nonmarital fertility in the U.S.” Social Forces 70: 977-1011.

Blossfeld, H.-P. 1987. "Labor-Market Entry and the Sexual Segregation of Careers in the Federal Republic of Germany." American Journal of Sociology 93: 89-118. and J. Huinink. 1991. "Human Capital Investments or Norms of Role Transition? How Women's Schooling and Career Affect the Process of Family Formation.” American Journal of Sociology 97: 143-168.

Brewster, K.L. and R.R. Rindfuss. 2000. "Fertility and Women's Employment in Industrialized Nations." Annual Review of Sociology 26: 271-296.

Coale, A.J. 1992. "Age of Entry into Marriage and the Date of the Initiation of Voluntary Birth Control.” Demography 29: 333-341.

Guo, G. and H. Zhao. 2000. "Multilevel Modeling for Binary Data." Annual Review of Sociology 26: 441-462.

Hank, K. 2001. "Regional Fertility Differences in Western Germany: An Overview of the Literature and Recent Descriptive Findings." International Journal of 
Population Geography 7: 243-257.

---- 2002a. "Regional Social Contexts and Individual Fertility Decisions: A Multilevel Analysis of First and Second Births in Western Germany." European Journal of Population 18: forthcoming.

----- . 2002b. "The Geographic Context of Male Nuptiality in Western Germany During the 1980s and 1990s." Mimeo. Max Planck Institute for Demographic Research: Rostock.

and Kreyenfeld. 2002. "Modes of Childcare and the Difficult Compatibility of

Childrearing and Employment in (Western) Germany." Materialien zur Bevölkerungswissenschaft 105: forthcoming.

Hauser, R.M. 1974. "Contextual Analysis Revisited." Sociological Methods \& Research 2: 365-375.

Heckhausen, J. 1999. Developmental Regulation in Adulthood. Age-Normative and Sociostructural Constraints as Adaptive Challenges. Cambridge: Cambridge University Press.

Hoem, B. 2000. "Entry into motherhood in Sweden: the influence of economic factors on the rise and fall in fertility, 1986-1997." Demographic Research [Online] 2, available http://www.demographic-research.org/Volumes/Vol2/4.

Huinink, J. and M. Wagner. 1989. "Regionale Lebensbedingungen, Migration und Familienbildung." Kölner Zeitschrift für Soziologie und Sozialpsychologie 41: 669-689.

Jencks, C. and S.E. Mayer. 1990. "The Social Consequences of Growing Up in a Poor Neighborhood." Pp.111-186 in Inner-City Poverty in the United States, edited by L.E. Lynn and M.G.H. McGeary. Washington: National Academy Press.

Konietzka, D. and M. Kreyenfeld. 2002. “Women's Employment and Non-Marital Childbearing: A Comparison of East and West Germany in the 1990s." Population 57: forthcoming. 
Kopp, J. 2000. “Geburtenentwicklung in Ost- und Westdeutschland.” Pp.83-135 in Solidarität, Lebensformen und regionale Entwicklung, edited by H. Bertram et al. Opladen: Leske+Budrich.

Kravdal, Ø. 1996. "How the local supply of day-care centers influences fertility in Norway: A parity-specific approach.” Population Research and Policy Review 15: 201-218.

Kravdal, Ø. 2002. "The impact of individual and aggregate unemployment on fertility in Norway". Demographic Research [Online] 6, available http://www.demographic-research.org/Volumes/Vol6/10.

Lesthaeghe, R. and G. Moors. 2000. "Life course transitions and value orientations: selection and adaptation." Interuniversity Papers in Demography WP 2000-7, available http://www.vub.ac.be/SOCO/IPDWP2000-7.pdf.

Lesthaeghe, R. and K. Neels. 2001. "From the First to the Second Demographic Transition: An Interpretation of the Spatial Continuity of Demographic Innovation in France, Belgium and Switzerland." Paper presented at the Euresco Conference on 'The Second Demographic Transition in Europe', Bad Herrenalb, June 23-28.

Lesthaeghe, R. and J. Surkyn. 1988. "Cultural Dynamics and Economic Theories of Fertility Change." Population and Development Review 14: 1-45.

Lichter, D.T., F.B. LeClere, and D.K. McLaughlin. 1991. "Local Marriage Markets and the Marital Behavior of Black and White Women." American Journal of Sociology 96: 843-867.

Lillard, L.A. and C.W.A. Panis. 2000. aML Multilevel Multiprocess Statistical Software, Release 1.0. Los Angeles: EconWare.

Marini, M.M. 1984. "Age and Sequencing Norms in the Transition to Adulthood." Social Forces 63: 229-244.

Reher, D.S. 1998. "Family Ties in Western Europe: Persistent Contrasts.” Population and Development Review 24: 203-234. 
Rindfuss, R.R., S.P. Morgan, and K. Offutt. 1996. "Education and the Changing Pattern of American Fertility: 1963-1989.” Demography 33: 277-290.

Settersten, R.A. and G.O. Hägestad. 1996. "What's the Latest? Cultural Age Deadlines for Family Transitions." The Gerontologist 36: 178-188.

Snijders, T.A.B. and R.J. Bosker. 1999. Multilevel analysis: An introduction to basic and advanced multilevel modeling. London: Sage.

SOEP Group. 2001. "The German Socio-Economic Panel (GSOEP) after more than 15 years - Overview." Pp.7-14 in Proceedings of the 2000 Fourth International Conference of German Socio-Economic Panel Study Users (GSOEP2000) (Vierteljahrshefte zur Wirtschaftsforschung 70), edited by E. Holst et al.

South, S.J. 2001. "The Geographic Context of Divorce: Do Neighborhoods Matter?" Journal of Marriage and the Family 63: 755-766.

------ and K.D. Crowder. 2000. “The declining significance of neighborhoods? Marital transitions in community context." Social Forces 78: 1067-1099. and K.M. Lloyd. 1992a. "Marriage Opportunities and Family Formation: Further Implications of Imbalanced Sex Ratios." Journal of Marriage and the Family 54: 440-451.

and K.M. Lloyd. 1992b. "Marriage Markets and Nonmarital Fertility in the United States.” Demography 29: 247-264.

Statistische Ämter des Bundes und der Länder (eds.). 1999. Statistik regional - Daten und Informationen der statistischen Ämter des Bundes und der Länder. CD-ROM.

Teachman, J. and K. Crowder. 2002. "Multilevel Models in Family Research: Some Conceptual and Methodological Issues." Journal of Marriage and the Family 64: 280-294.

Yamaguchi, K. 1991. Event History Analysis. Newbury Park: Sage. 


\section{Tables:}

\section{Table 1: Variable description}

\begin{tabular}{|c|c|}
\hline \multicolumn{2}{|r|}{ Dependent variables } \\
\hline First marriage / First birth & $\begin{array}{l}\text { Binary variable that equals } 1 \text {, if the woman experiences her first } \\
\text { marriage (birth, respectively) within a one-year interval in the period } \\
1984 \text { to } 1999 \text {. }\end{array}$ \\
\hline \multicolumn{2}{|r|}{ Individual characteristics } \\
\hline Age & Woman's age and age-squared. The age range is 20 to 35 years. \\
\hline Education & $\begin{array}{l}\text { Time-varying binary variables, indicating the woman's highest } \\
\text { educational degree at the time of the interview: in education, no } \\
\text { degree, vocational degree (reference category), university degree. }\end{array}$ \\
\hline Child $^{\mathrm{a}}$ & $\begin{array}{l}\text { Time-varying binary variable that equals } 1 \text {, if the woman is mother of } \\
\text { (at least) one child. }\end{array}$ \\
\hline Marital status ${ }^{\mathrm{b}}$ & Time-varying binary variable that equals 1 , if the woman is married. \\
\hline Foreigner & $\begin{array}{l}\text { Time-constant binary variable that equals } 1 \text {, if the woman belongs to } \\
\text { the foreigner-sample of the GSOEP. }\end{array}$ \\
\hline \multicolumn{2}{|r|}{ Regional characteristics } \\
\hline Degree of urbanization & $\begin{array}{l}\text { Time-constant binary variables, indicating whether the district is } \\
\text { defined as agglomeration (reference category), as urban area, or as } \\
\text { rural area. }\end{array}$ \\
\hline Proportion of men ${ }^{\mathrm{a}}$ & $\begin{array}{l}\text { Average proportion of men in the local population aged } 25 \text { to } 30 \text { in } \\
1995-1997 \text { (in \%) (time-constant). }\end{array}$ \\
\hline Day-care provision $^{\mathrm{b}}$ & $\begin{array}{l}\text { Local provision of day care slots in Kindergarten per } 1000 \text { children } \\
\text { aged 3-6 (time-varying, 1986/1994). }\end{array}$ \\
\hline Tertiary sector & Local share of employees in trade (in \%) (time-varying, 1987/1995). \\
\hline Unemployment rate & Local unemployment rate (in \%) (time-varying, 1987/1996). \\
\hline $\begin{array}{l}\text { Female labor force participation } \\
\text { rate (FLPR) }\end{array}$ & $\begin{array}{l}\text { Local female labor force participation rate (in \%) (time-varying, } \\
\text { 1987/1995). }\end{array}$ \\
\hline Crude marriage rate $(\mathrm{CMR})^{\mathrm{a}}$ & $\begin{array}{l}\text { Average of local crude marriage rates in } 1986 \text { and } 1993 \text { (time- } \\
\text { constant). }\end{array}$ \\
\hline Crude birth rate $(\mathrm{CBR})^{\mathrm{b}}$ & Average of local crude birth rates in 1989 and 1995 (time-constant). \\
\hline $\begin{array}{l}\text { Ideational homogeneity index } \\
\text { (IHI) }\end{array}$ & $\begin{array}{l}\text { Time-constant binary variable that equals } 1 \text {, if a single party received } \\
\text { more than } 50 \text { per cent of the local votes in two recent elections } \\
\text { (European parliament } 1989 \text {, state parliament 1995/1999), and more } \\
\text { than two thirds of the population share the same denominational } \\
\text { affiliation (Protestant or Catholic). }\end{array}$ \\
\hline \multicolumn{2}{|c|}{$\begin{array}{l}\text { Note: } \\
{ }^{a} \text { Variable is used in the analysis of first marriages only. } \\
\text { b Variable is used in the analysis of first births only. }\end{array}$} \\
\hline
\end{tabular}


Table 2: Descriptive sample statistics

\begin{tabular}{|c|c|c|}
\hline Variable & $\begin{array}{l}\text { First marriage } \\
\text { Mean }(\text { Stdv. })^{\mathrm{a}}\end{array}$ & $\begin{array}{c}\text { First birth } \\
\text { Mean }(\text { Stdv. })^{\mathrm{a}}\end{array}$ \\
\hline Individual level & & \\
\hline Age & $24.8(3.9)$ & $25.5(4.1)$ \\
\hline Age squared & $629.9(206.8)$ & $665.0(218.1)$ \\
\hline In education & .22 & .17 \\
\hline No degree & .17 & .18 \\
\hline Vocational degree & .53 & .57 \\
\hline University degree & .07 & .08 \\
\hline Child & .09 & - \\
\hline Marital status & - & .27 \\
\hline Foreigner & .22 & .23 \\
\hline Regional level & & \\
\hline Agglomeration & .59 & .60 \\
\hline Urbanized area & .25 & .25 \\
\hline Rural area & .15 & .15 \\
\hline Proportion of men & $51.3(1.2)$ & - \\
\hline Day-care provision & - & $825.5(175.0)$ \\
\hline Tertiary sector & $17.2(3.9)$ & $17.2(3.9)$ \\
\hline Unemployment rate & $8.8(3.2)$ & $8.7(3.2)$ \\
\hline FLPR & $41.4(3.5)$ & $41.2(3.5)$ \\
\hline CMR & $7.5(0.5)$ & - \\
\hline CBR & - & $10.2(.9)$ \\
\hline IHI & .10 & .10 \\
\hline $\mathrm{N}$ (events) & 746 & 1,025 \\
\hline $\mathrm{N}$ (districts) & 288 & 300 \\
\hline $\mathrm{N}$ (women) & 2,266 & 2,892 \\
\hline $\mathrm{N}$ (records) & 10,077 & 13,537 \\
\hline
\end{tabular}

Source: GSOEP 1984-1999, DJI Regionaldatenbank, Statistik regional 1999, author's calculations 
Table 3: 'First marriage' - Results of multilevel discrete-time logit models, 1984 to 1999

\begin{tabular}{|c|c|c|c|c|c|c|c|c|c|c|c|c|c|c|c|c|c|c|c|c|c|}
\hline & \multicolumn{3}{|c|}{ Model 1} & \multicolumn{3}{|c|}{ Model 2} & \multicolumn{3}{|c|}{ Model 3} & \multicolumn{3}{|c|}{ Model 4} & \multicolumn{3}{|c|}{ Model 5} & \multicolumn{3}{|c|}{ Model 6} & \multicolumn{3}{|c|}{ Model 7} \\
\hline & $\beta$ & s.e. & Sig. & $\beta$ & s.e. & Sig. & $\beta$ & s.e. & Sig. & $\beta$ & s.e. & Sig. & $\beta$ & s.e. & Sig. & $\beta$ & s.e. & Sig. & $\beta$ & s.e. & Sig. \\
\hline Age & - & & & 1.19 & .16 & $* * *$ & .98 & .16 & $* * *$ & 1.00 & .17 & $* * *$ & 1.00 & .17 & $* * *$ & 1.03 & .17 & $* * *$ & 1.03 & .17 & $* * *$ \\
\hline Age squared & - & & & -.02 & .00 & $* * *$ & -.02 & .00 & $* * *$ & -.02 & .00 & $* * *$ & -.02 & .00 & $* * *$ & -.02 & .00 & $* * *$ & -.02 & .00 & $* * *$ \\
\hline In education $^{\mathrm{a}}$ & - & & & - & & & -1.18 & .16 & $* * *$ & -1.18 & .16 & $* * *$ & -1.15 & .16 & $* * *$ & -1.14 & .16 & $* * *$ & -1.14 & .16 & $* * *$ \\
\hline No degree ${ }^{a}$ & - & & & - & & & -.11 & .11 & & -.31 & .11 & $* * *$ & -.31 & .11 & $* * *$ & -.32 & .11 & $* * *$ & -.32 & .11 & $* * *$ \\
\hline University degree $^{a}$ & - & & & - & & & -.06 & .15 & & -.06 & .15 & & .06 & .15 & & .06 & .16 & & .06 & .16 & \\
\hline Child & - & & & - & & & - & & & 1.00 & .09 & $* * *$ & 1.01 & .10 & $* * *$ & 1.02 & .10 & $* * *$ & 1.02 & .10 & $* * *$ \\
\hline Foreigner & - & & & - & & & - & & & .19 & .10 & $*$ & .18 & .10 & $*$ & .20 & .11 & $*$ & .19 & .11 & $*$ \\
\hline Urbanized area $^{\mathrm{b}}$ & - & & & - & & & - & & & - & & & -.05 & .11 & & -.11 & .12 & & -.08 & .13 & \\
\hline Rural area $^{\mathrm{b}}$ & - & & & - & & & - & & & - & & & -.02 & .13 & & -.12 & .14 & & .02 & .19 & \\
\hline Proportion of men & - & & & - & & & - & & & - & & & - & & & .01 & .04 & & .02 & .04 & \\
\hline Tertiary sector & - & & & - & & & - & & & - & & & - & & & -.01 & .02 & & -.01 & .02 & \\
\hline Unemployment rate & - & & & - & & & - & & & - & & & - & & & -.02 & .02 & & -.02 & .02 & \\
\hline FLPR & - & & & - & & & - & & & - & & & - & & & -.01 & .01 & & -.02 & .02 & \\
\hline CMR & - & & & - & & & - & & & - & & & - & & & - & & & .01 & .06 & \\
\hline IHI & - & & & - & & & - & & & - & & & - & & & - & & & -.34 & .21 & $*$ \\
\hline Constant & -2.52 & .04 & $* * *$ & -18.37 & 2.05 & $* * *$ & -15.03 & 2.11 & $* * *$ & -15.28 & 2.19 & $* * *$ & -15.25 & 2.19 & $* * *$ & -14.44 & 2.24 & $* * *$ & -14.36 & 2.42 & $* * *$ \\
\hline$\sigma_{u}$ & .24 & .09 & $* * *$ & .29 & .09 & $* * *$ & .28 & .09 & $* * *$ & .33 & .09 & $* * *$ & .33 & .09 & $* * *$ & .34 & .09 & $* * *$ & .32 & .09 & $* * *$ \\
\hline-2 Log likelihood ${ }^{\mathrm{c}}$ & 5316 & & - & 5221 & & $* * *$ & 5136 & & $* * *$ & 5058 & & $* * *$ & 5058 & & & 5051 & & & 5047 & & \\
\hline \multicolumn{22}{|c|}{ Note: } \\
\hline
\end{tabular}

Source: GSOEP 1984-1999, DJI Regionaldatenbank, Statistik regional 1999, author's calculations 
Table 4: 'First birth' - Results of multilevel discrete-time logit models, 1984 to 1999

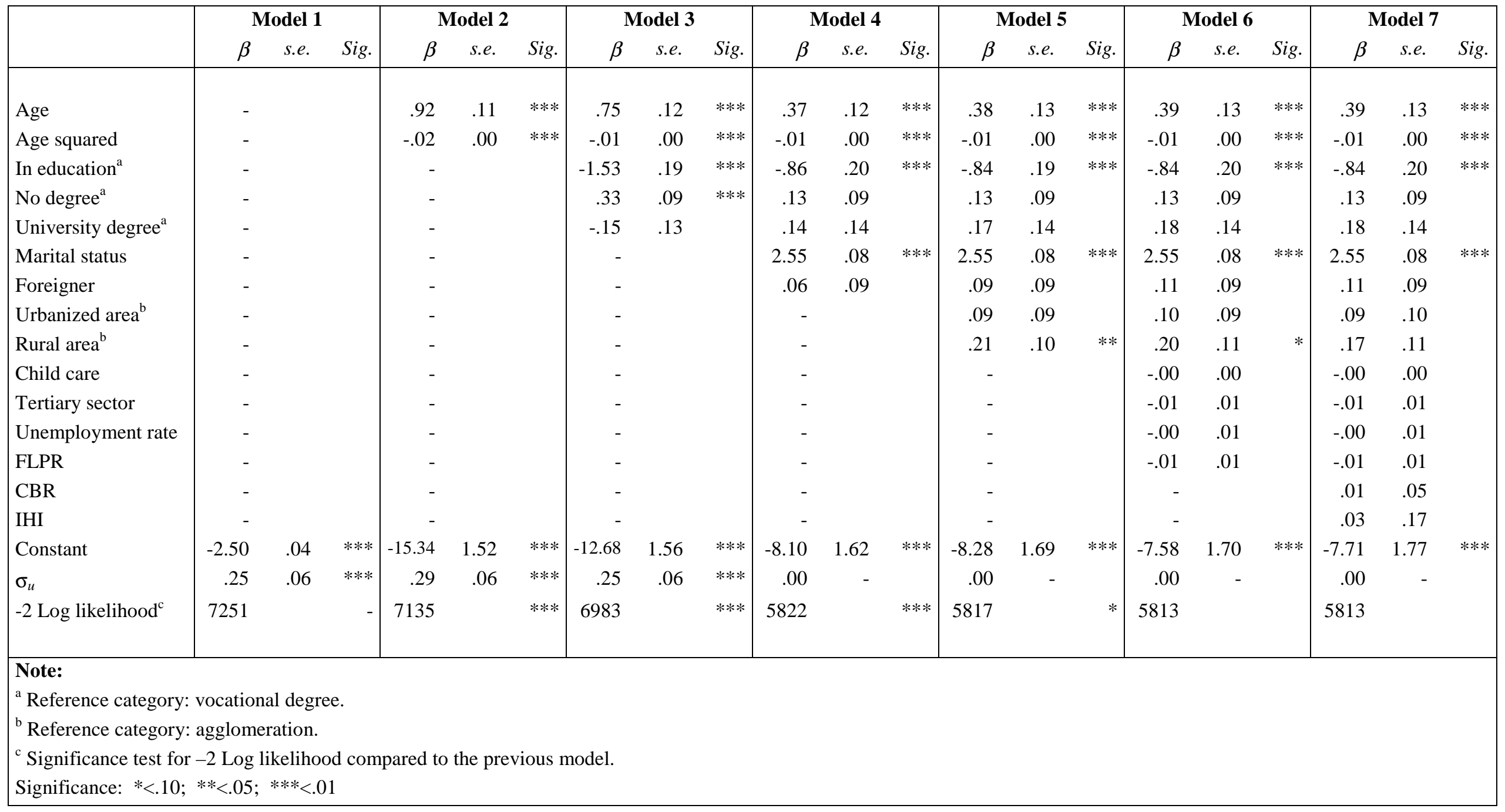

Source: GSOEP 1984-1999, DJI Regionaldatenbank, Statistik regional 1999, author's calculations 